\title{
Insulin Binding and Insulin Action in Rat Fat Cells after Adrenalectomy
}

\author{
H. Häring, C. Calle, A. Bug, R. Renner, K. D. Hepp, and W. Kemmler \\ Institut für Diabetesforschung, München, FRG
}

Summary. Insulin binding and the effect of insulin on the transport of 3-O-methylglucose, lipogenesis from glucose, glucose oxidation and lipolysis was studied in fat cells of adrenalectomised rats and of a control group of sham-operated rats. The serum insulin level of the adrenalectomised rats $(0.7 \mathrm{ng} / \mathrm{ml})$ was lower than that of the controls $(1.6 \mathrm{ng} / \mathrm{ml})$. In adrenalectomised rats as compared to sham-operated rats the insulin concentrations causing half-maximal effect were reduced by $50 \%$ in lipogenesis and antilipolysis and by $30 \%$ in glucose transport. The increase in sensitivity to submaximal insulin concentrations was not observed in glucose oxidation. The maximal responsiveness was unchanged in all test systems. The increase in sensitivity in three of the four studied insulin effects may be related to the $37 \%$ increase in the binding capacity of fat cells from adrenalectomised compared with sham-operated rats. The unchanged sensitivity with respect to glucose oxidation indicates possible post-receptor modulation. When adrenalectomised rats were substituted with either insulin or cortisol serum insulin levels were elevated above normal; however, the changes in the receptor were prevented in the cortisol supplemented rats and only partially in the insulin supplemented rats. The observation suggests, that the insulin receptor is regulated not only by the serum insulin level but also by cortisol.

Key words: Adrenalectomy, insulin receptor, cortisol, insulin effect, glucose transport, glucose oxidation. lipogenesis, antilipolysis.

An inverse relationship of the serum insulin levels and the number of insulin receptors is shown in vivo in different hyperinsulinaemic animal models [1-5] and also in patients with obesity $[6,7]$ or maturity onset diabetes $[8,9]$ showing relatively elevated insulin levels. In vitro the "down regulation" of the receptor by insulin has been demonstrated in lymphocytes [10] fat cells [11] and hepatocytes [12].

Greater than normal binding capacity was first demonstrated in the insulin deficient state using the model of the genetically diabetic Chinese hamster [13]. This observation has been confirmed in other animal models with decreased insulin levels e. g. fasting $[14,15]$ and with streptozotocin diabetes [16-19].

The relationship of insulin binding and insulin action, however, is very complex. Changes in binding do not always regulate the overall insulin sensitivity of the target tissue in the expected way, since the insulin sensitivity may also be influenced by altered insulin effector systems behind the receptor. Thus binding and action are not correlated in all situations of insulin deficiency [14-17].

In this study another animal model with decreased insulin levels, the adrenalectomised rat was evaluated. Hypersensitivity to insulin is shown in vivo in patients with adrenal insufficiency [20] and in adrenalectomised animals [21]. The in vitro data on the insulin sensitivity after adrenalectomy are somewhat contradictory [22-25]. In this study we have tried to answer the following questions:

1. Is there an inverse relationship between insulin levels and the number of insulin receptors in the adrenalectomised rat?

2. Is there a correspondence between the well-known hypersensitivity to insulin in vivo in the state of adrenal insufficiency and the action of insulin in vitro?

3. What is the relation of insulin binding and action in this animal model with decreased insulin levels? 
Table 1. Characteristics of animals and fat cells

\begin{tabular}{lcccc}
\hline & $\begin{array}{l}\text { Adrenalectomised } \\
\text { rats (A) }\end{array}$ & $\begin{array}{l}\text { Sham-operated } \\
\text { rats (S) }\end{array}$ & $\begin{array}{l}\text { Adrenalectomised } \\
\text { rats with insulin } \\
\text { treatment (AI) }\end{array}$ & $\begin{array}{l}\text { Adrenalectomised } \\
\text { rats with cortisol } \\
\text { treatment (AC) }\end{array}$ \\
\hline Serum insulin $(\mathrm{ng} / \mathrm{ml})$ & $0.7 \pm 0.1$ & $1.6 \pm 0.2$ & $9.1 \pm 1.3$ & $3.0 \pm 0.2$ \\
Serum glucose $(\mathrm{mmol} / \mathrm{l})$ & $6.9 \pm 0.1$ & $7.6 \pm 0.15$ & $6.3 \pm 0.1$ & $8.1 \pm 0.1$ \\
Body weight $(\mathrm{g})$ & $194 \pm 3$ & $206 \pm 2$ & $206 \pm 2$ & $188 \pm 5$ \\
Fat cell diameter $(\mu \mathrm{m})$ & $74 \pm 2$ & $77 \pm 3$ & $79 \pm 3$ & $72 \pm 2$ \\
Total lipid $\left(\mathrm{mg} / 10^{5}\right.$ cells) & $11.4 \pm 1.1$ & $11.9 \pm 1.3$ & $11.6 \pm 0.7$ & $11.7 \pm 1.3$ \\
\hline
\end{tabular}

The values for glucose and insulin are fed values and give the mean of 8 determinations \pm SEM for each group. The sham-operated group was not pair-fed. The body weight was determined in 32 animals per group, the fat cell diameter in 300 cells of 8 animals per group and the total lipids in 8 animals per group. The differences in the insulin and glucose levels between all groups were statistically significant $(p \leqslant$ $0.001)$. The body weights of group $A$ and $A C$ were statistically significant $(p \leqslant 0.001)$ different from $S$ and AI. All other differences were not statistically significant

\section{Materials and Methods}

\section{Materials}

[ $\left.{ }^{125} \mathrm{I}\right]$-beef insulin (specific activity $24-28 \mathrm{mCi} / \mathrm{mg}$ ) and unlabelled monocomponent beef insulin $(27 \mathrm{U} / \mathrm{mg})$ were generous gifts from the Novo Company, Copenhagen; insulin (Depot Hoechst CR) and hydrocortisone were provided by Farbwerke Hoechst $A G$, Frankfurt/Main; bovine albumin was purchased from Behring Co., Marburg; 3-O-methyl-D- $\left[{ }^{14} \mathrm{C}\right]$-glucose (specific activity $50 \mathrm{mCi} /$ $\mathrm{mmol}$ ), D- $\left[1-{ }^{14} \mathrm{C}\right]$-glucose (specific activity $50 \mathrm{mCi} / \mathrm{mmol}$ ) were from the Radiochemical Centre, Amersham, and DL-isopropylarterenol- $\mathrm{HCl}$ from Serva Co., Heidelberg. Szintigel from Roth Co., Karlsruhe, was used as scintillator. All other substances were reagent grade from Merck Co., Darmstadt.

\section{Methods}

Animals: Five groups of male Wistar rats (weight $150-170 \mathrm{~g}$ ) were studied: Group A, rats were adrenalectomised, fed ad libitum, and maintained on $0.154 \mathrm{~mol} / 1$ saline; Group $\mathrm{S}$, animals were shamoperated and fed ad libitum; Group SP, animals were sham-operated and pair-fed with group A rats during the test period; Group $A C$, adrenalectomised rats were substituted from the day of operation with cortisol $(2 \times 2.5 \mathrm{mg}$ hydrocortisone/day/animal), maintained on $0.154 \mathrm{~mol} / \mathrm{l}$ saline, and fed ad libitum. In the fifth group (AI) adrenalectomised rats received from the day of operation insulin $(2 \times 60 \mu \mathrm{g}$ Depot Hoechst CR/day/animal), they were maintained on $50 \mathrm{~g} / 1$ glucose in $0.154 \mathrm{~mol} / 1$ saline and fed ad libitum. On the fifth day after surgery animals were sacrificed and isolated fat cells were prepared from the epididymal fat pads (26). In all assays a Krebs-Ringer-Hepes-buffer [27], $\mathrm{pH} 7.4$, containing $2.5 \mathrm{~g} / 100 \mathrm{ml}$ bovine albumin was used.

Insulin Binding: Adipocytes $\left(4-6 \times 10^{5} / \mathrm{ml}\right.$, test volume $\left.400 \mu \mathrm{l}\right)$ were incubated with $50 \mu \mathrm{l}$ of bovine $\left[{ }^{125} \mathrm{I}\right]$-insulin $(2 \mathrm{ng})$ and $\left.50 \mu\right]$ of unlabelled bovine insulin $(0.2 \mathrm{ng}$ to $20 \mu \mathrm{g})$ or $50 \mu \mathrm{l}$ of buffer. After incubation for $45 \mathrm{~min}$ at $25^{\circ} \mathrm{C}$ the adipocytes were separated from the medium by centrifugation through dinonylphthalate according to Gliemann et al. [28] and the cell layer was counted in a gamma counter. The amount of $\left[{ }^{125} \mathrm{I}\right]$-insulin bound in the presence of $20 \mu \mathrm{g}$ of unlabelled insulin was considered as non specific binding. It ranged from $7-13 \%$ of the total $\left[{ }^{124} \mathrm{I}\right]$-insulin bound in the absence of unlabelled insulin and was subtracted from each value. The non specific binding was not different in the five groups.

Determination of 3-0-methylglucose Transport: Fat cells $\left(5 \times 10^{6}\right)$ $\mathrm{ml})$ were incubated at $37^{\circ} \mathrm{C}$. Samples of $100 \mu \mathrm{l}$ were drawn together with $200 \mu \mathrm{l}$ of 3-0-methylglucose (final concentration $500 \mu \mathrm{mol} / 1,0.1 \mu \mathrm{Ci} 1-\left[{ }^{14} \mathrm{C}\right]-3-0$-methylglucose as tracer) into a mixing pipet (Gilson Medical Electronics, Villiers-le-Bel, France). After time intervals of 5, 15, 25, 40,60 and 120 seconds cells and medium were separated by centrifugation through dinonylphthalate [28]. The cell layer was dissolved in $200 \mu \mathrm{l}$ of diphenylethylamine and counted in $10 \mathrm{ml}$ scintillation fluid. The values thus obtained represent intracellular 3-0-methylglucose and 3-0methylglucose in the extracellular waterspace trapped in the cell layer. The extracellular part was estimated by an extrapolation of the initial linear uptake kinetic to time zero and the values thus obtained on the ordinate were subtracted from each measurement. For the determination of the insulin effect fat cells were preincubated with insulin $(60 \mathrm{pg}-0.4 \mu \mathrm{g} / \mathrm{ml})$ for $15 \mathrm{~min}$ at $37^{\circ} \mathrm{C}$. At this time point an equilibrium of the insulin effect was reached at all insulin concentrations used.

Antilipolysis: Adipocytes $\left(1 \times 10^{5}\right.$ in a test volume of $\left.1 \mathrm{ml}\right)$ were incubated for $1 \mathrm{~h}$ at $37^{\circ} \mathrm{C}$ with isoproterenol $10^{-6} \mathrm{~mol} / 1$ and insulin at the concentrations described for the individual experiments. The cells were separated from the medium by filtration through paper filters. The glycerol content of the medium was determined enzymatically [29].

Glucose Oxidation and Lipogenesis: Fat cells $\left(4 \times 10^{4}\right.$ in a test volume of $1 \mathrm{ml}$ ) were incubated with $1 \mathrm{mmol} / 1$ glucose for $1 \mathrm{~h}$ at $37^{\circ} \mathrm{C}$. For glucose oxidation studies $\left[{ }^{14} \mathrm{C}\right]$-glucose, $(0.1 \mu \mathrm{Ci})$ and for lipogenesis $2-\left[{ }^{3} \mathrm{H}\right]$-glucose $(0.1 \mu \mathrm{Ci})$ were added respectively as tracers. The incorporation of glucose into lipids was determined according to Moody et al. [30]. $\left[{ }^{14} \mathrm{CO}_{2}\right]$-production from 1- $\left[{ }^{14} \mathrm{C}\right]-$ glucose was determined as described by Weitzel et al. [31]. Insulin was measured by radioimmunoassay with rat insulin standards according to Heding et al. [32]. The coefficient of variation of the assay was $7.6 \%$, the sensitivity i. e. the smallest quantity of insulin that can be distinguished as significantly different from zero ( \pm $2 \mathrm{SD}$ ) was $0.2 \mathrm{ng} / \mathrm{ml}$. Total lipids were determined as described by Zöllner and Kirsch [33], and protein by the method of Lowry et al. [34]. Fat cell diameter was measured under a Zeiss microscope with an ocular micrometer [35]. Statistical analysis was performed using Student's t-test. 


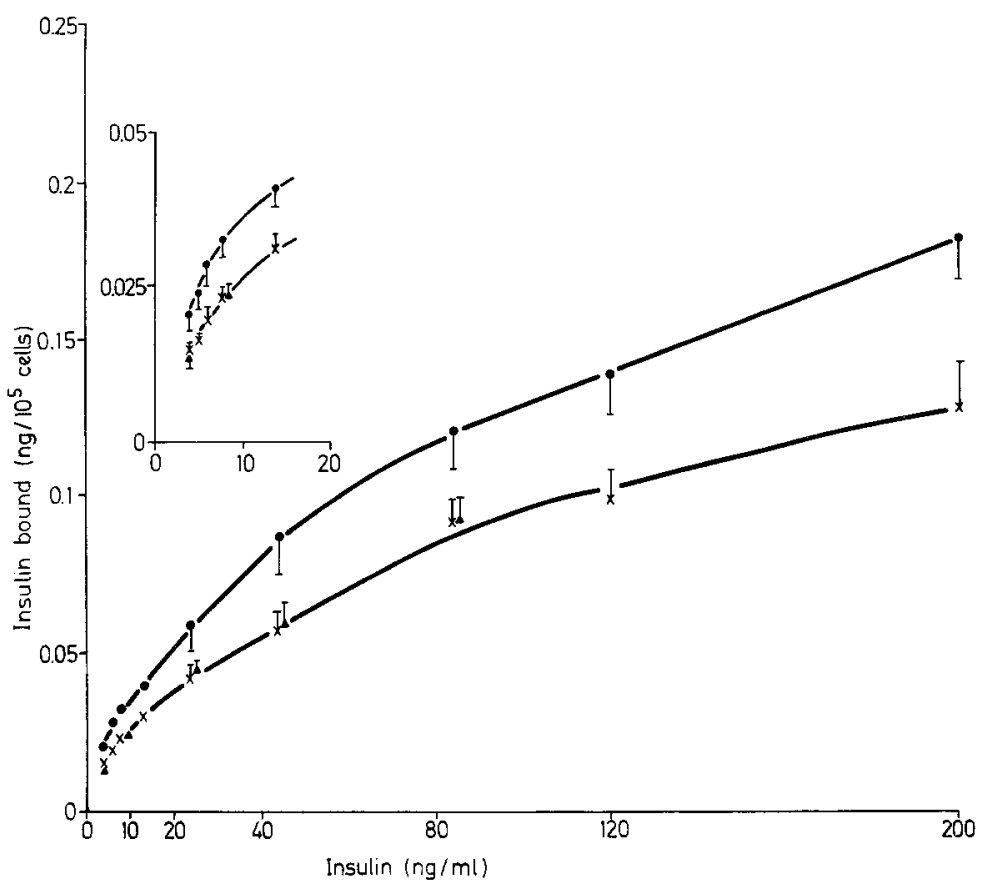

Fig. 1. Insulin binding to adipocytes of the adrenalectomised group $(\bullet)$, the sham-operated group $(X)$, and the sham-operated pair-fed group (A). The ordinate indicates the total insulin bound (radioactive labelled and unlabelled insulin), the abscissa the amount of total insulin in the incubation medium. Values for the adrenalectomised and the sham-operated group represent the mean of 8 experiments $\pm S E M$, for the control-fed group the mean of 5 experiments. The differences between the adrenalectomised and the sham-operated group were statistically significant at all insulin concentrations used in the test $(p \leqslant 0.01)$. The binding at lower concentrations is shown in the insert. For experimental details see Methods section

\section{Results}

Effect on Body Weight, Glucose and Insulin. The effects of adrenalectomy, substitution with cortisol, and insulin treatment on body weight, serum glucose and serum insulin levels are shown on Table 1. The adrenalectomised animals were lighter because of decreased food intake [36], therefore, an additional pair-fed control group of sham-operated animals was introduced. Their body weight was $189 \pm 10 \mathrm{~g}$ ( $\mathrm{n}=$ 11). There were slight but significant differences in the serum glucose levels among the various groups. Adrenalectomy led to a decrease in serum insulin by $56 \%$, while substitution with cortisol increased the level to $188 \%$ of the control value. No differences in the diameter or lipid content of the fat cells was found between the various groups.

Insulin Binding. Insulin binding was significantly increased in the adrenalectomised group (Fig. 1). The binding curves for the sham-operated and pairfed animals were identical, which shows that there was no influence of the reduced food intake on insulin binding. Figure 2 depicts a Scatchard-analysis of the binding data from the different groups. The increase of the receptor capacity of fat cells after adrenalectomy was prevented by cortisol substitution (Fig. $2 \mathrm{~A}$ ). Insulin substitution prevented the increase in the total binding capacity (Fig. 2B), however an upregulation of binding at lower insulin concentrations is still evident.
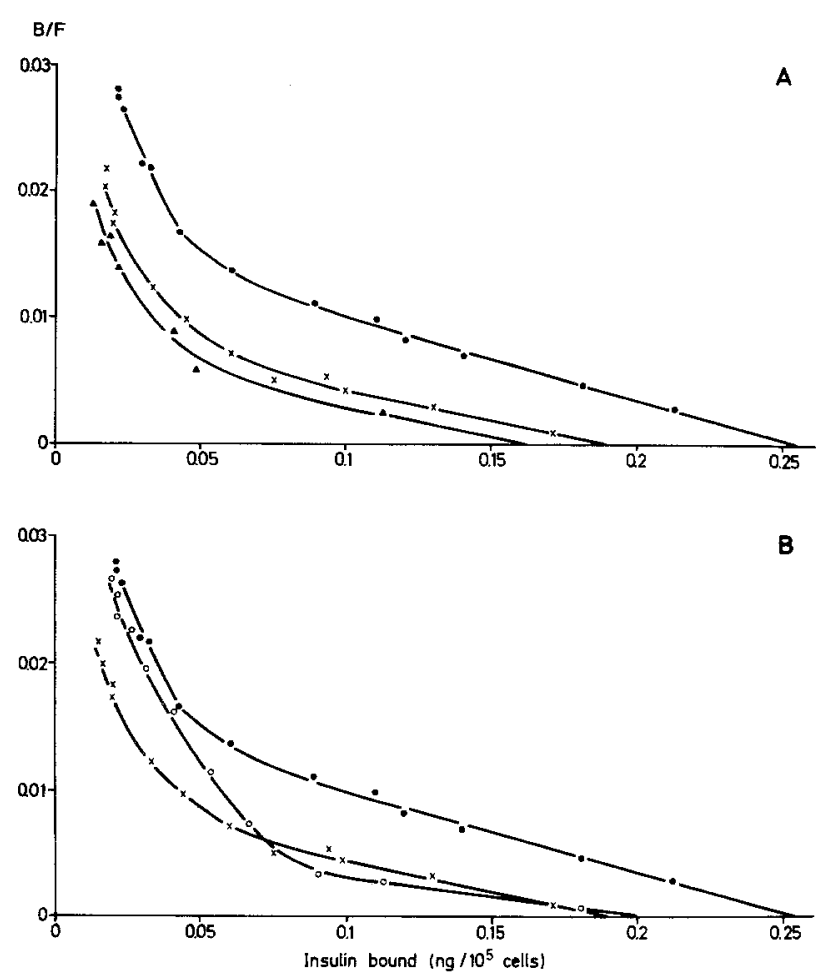

Fig. $2 \mathrm{~A}$ and $\mathbf{B}$. Scatchard plot analysis of insulin binding. A Fat cells of sham-operated $(X)$, adrenalectomised $(\bullet)$ and adrenalectomised, cortisol substituted rats $(\mathbf{\Lambda})$. The points indicate the mean of 8 experiments. B The plot of insulin binding to fat cells of adrenalectomised, insulin substituted rats $(O)$ and for comparison the plots of sham-operated $(X)$ and adrenalectomised $(\bullet)$ rats. The points indicate the mean of 8 experiments. The SEM in the adrenalectomised, insulin or cortisol substituted groups ranged from $7.5-14 \%$. For experimental details see Methods section 


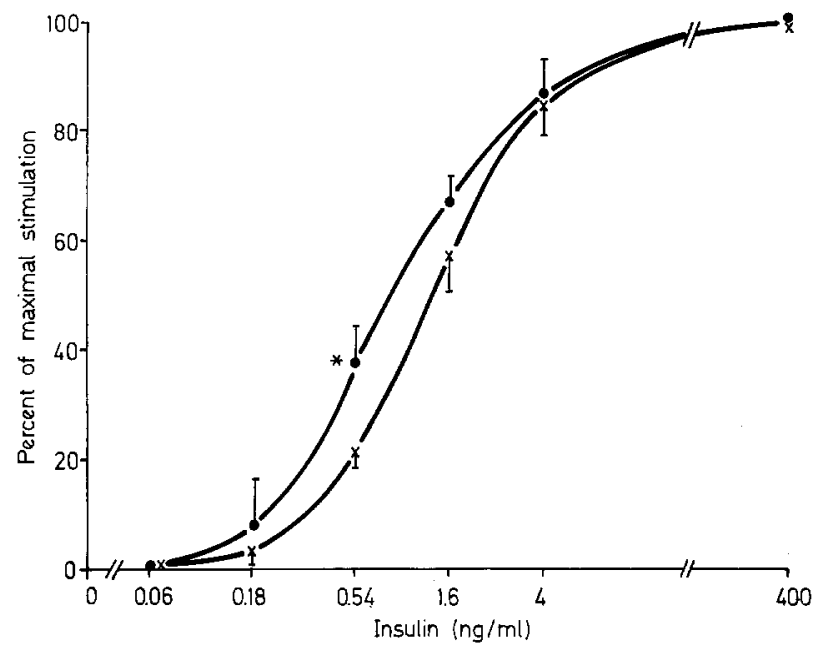

Fig. 3. Dose-response curve of the effect of insulin on 3-0-methylglucose transport into fat cells of adrenalectomised (-), and shamoperated $(X)$ rats. The points indicate the mean of 7 experiments \pm SEM. Data are expressed as percent of the maximal stimulation. The difference at the insulin concentration $0.54 \mathrm{ng} / \mathrm{ml}$ as indicated by the asterix is statistically significant $(p \leqslant 0.025)$. For experimental details see Methods section

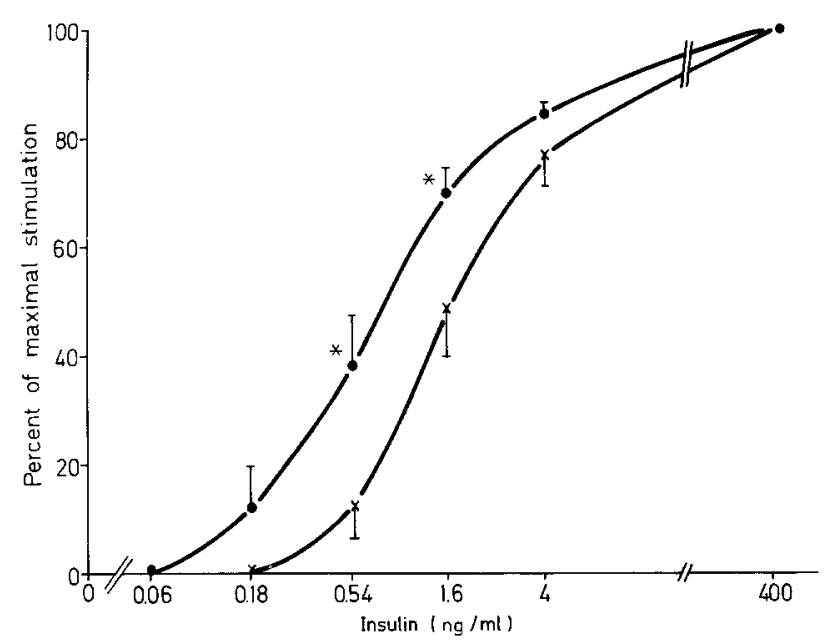

Fig. 4. Incorporation of $\left[{ }^{3} \mathrm{H}\right]$ from glucose into total lipids of fat cells from adrenalectomised $(\bullet)$ and sham-operated rats $(X)$. The points indicate the mean of 6 experiments \pm SEM. Data are expressed as percent of maximal stimulation. * $p<0.025$. For experimental details see Methods section

Metabolic Effects of Insulin. The basal values of 3-0methylglucose uptake were significantly higher in the adrenalectomised rats $\left(63 \pm 4 \mathrm{pmol} / 10^{5}\right.$ cells $\left./ 15 \mathrm{~s}\right)$ as compared to the controls $\left(35 \pm 3 \mathrm{pmol} / 10^{5}\right.$ cells $/$ $15 \mathrm{~s} ; \mathrm{p}<0.01$ ). The maximal values in the presence of $0.4 \mu \mathrm{g} / \mathrm{ml}$ of insulin were $156 \pm 14$ in the adrenalectomised, and $128 \pm 10 \mathrm{pmol} / 10^{5}$ cells $/ 15 \mathrm{~s}$

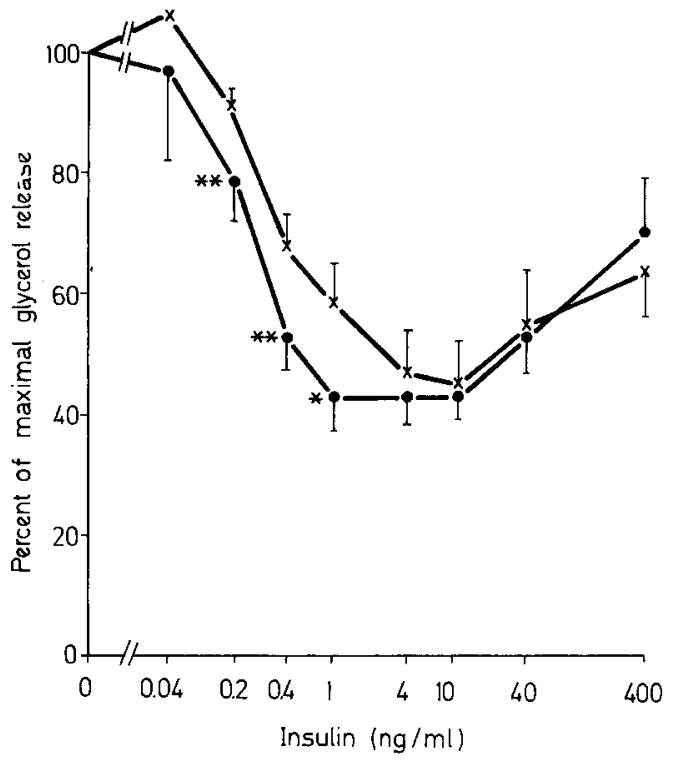

Fig. 5. Antilipolytic action of insulin in fat cells of adrenalectomised $(0)$ and sham-operated rats $(X)$. Points indicate the mean of 9 experiments \pm SEM and represent the percent inhibition of the glycerol release induced with $10^{-6} \mathrm{M}$ isoproterenol. * $\mathrm{p} \leqslant$ $0.05, * * \mathrm{p} 0.025$. For experimental details see Methods section

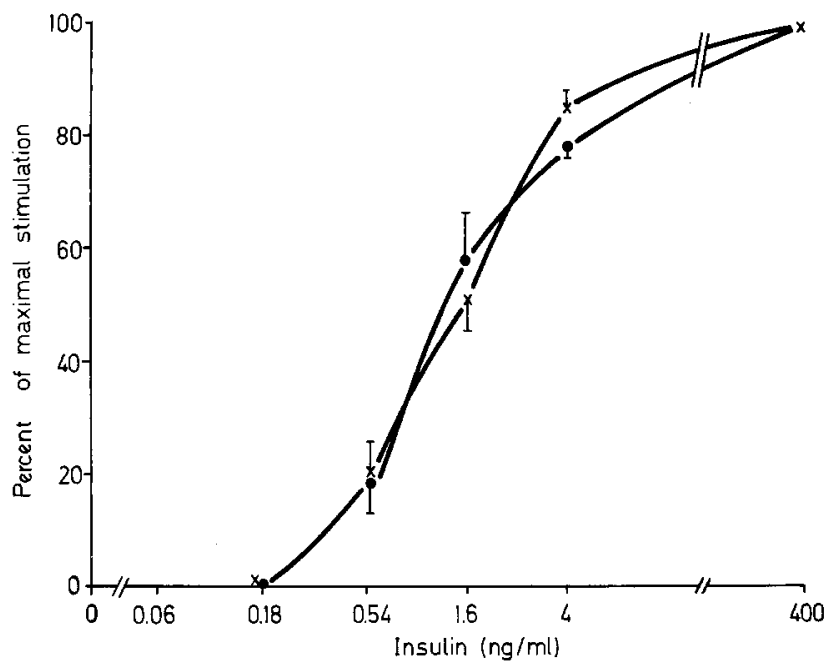

Fig. 6. Effect of insulin on the $\left[{ }^{14} \mathrm{CO}_{2}\right]$-production from $1-\left[{ }^{14} \mathrm{C}\right]-$ glucose of fat cells from adrenalectomised rats $(\bullet)$ and shamoperated rats $(X)$. Points indicate the mean of 6 experiments \pm SEM. For experimental details see Methods section

in the sham-operated rats. The maximal increase of the transport capacity was thus the same in the two groups if it is expressed as the difference of maximal and basal uptake, but was lower in the adrenalectomised groups if it is expressed as ratio of maximal and basal value. Figure 3 shows the insulin effect as percentage of the difference of basal and maximally 
stimulated uptake. At submaximal insulin concentrations glucose transport was significantly more stimulated in cells from the adrenalectomised groups. Increased sensitivity of cells from adrenalectomised rats towards submaximal concentrations of insulin was also evident when the incorporation of $2-\left[{ }^{3} \mathrm{H}\right]-$ glucose into total lipids was measured (Fig. 4). In this case the basal and the maximally stimulated rates of lipid formation were the same. Another index, the antilipolytic effect of insulin, again revealed an increase in sensitivity to insulin at submaximal concentrations (Fig. 5). As shown before [37], fat cells prepared from the adrenalectomised rats were less sensitive to the effect of the catecholamine. Basal rates of glycerol release were $19.5 \pm 3.9 \mathrm{nmol} / 10^{5}$ cells $/ \mathrm{h}$ in $\mathrm{S}$ and $19.9 \pm 3.9 \mathrm{nmol} / 10^{5}$ cells $/ \mathrm{h}$ in $\mathrm{A}$. Isoproterenol $\left(10^{-6} \mathrm{~mol} / \mathrm{l}\right)$ stimulated rates of glycerol release were $334 \pm 34 \mathrm{nmol} / 10^{5}$ cells $/ \mathrm{h}$ in S and $269 \pm 30 \mathrm{nmol} / 10^{5} \mathrm{cells} / \mathrm{h}$ in $\mathrm{A}$. In contrast to these dose-response characteristics, no change in the effect of insulin on glucose-1-[ $\left[{ }^{14} \mathrm{C}\right]$-oxidation was observed (Fig. 6). The basal rates, $2.5 \pm 0.3 \mathrm{nmol} / 10^{5}$ cells $/ \mathrm{h}$ for control and $2.2 \pm 0.3 \mathrm{nmol} / 10^{5}$ cells $/ \mathrm{h}$ for the adrenalectomised group as well as the maximal rates, $12.2 \pm 1.4 \mathrm{nmol} / 10^{5} \mathrm{cells} / \mathrm{h}$ and $10.8 \pm 1.6 \mathrm{nmol} / 10^{5}$ cells $/ \mathrm{h}$, respectively, were not different.

\section{Discussion}

The present data indicate, that fat cells from adrenalectomised rats have an increased insulin binding capacity as compared to controls. These results are in contrast to reports of Olefsky et al., who, without showing the data in detail, described no change in the insulin receptors of adrenalectomised rats [38]. Goldfine et al. [39] on the other hand, found indirect evidence for a possible influence of adrenalectomy on insulin binding, showing that the decreased binding induced by the transplantation of an ACTH, growth hormone and prolactin secreting tumour in rats can be reversed by adrenalectomy. In a very recent publication of Kahn et al. [40] an increase of insulin binding in fat cells of adrenalectomised rats was reported, which was solely due to increased affinity. A direct comparison of our binding data with those reported from Kahn et al. is difficult because different tracer concentrations were applied. In the range of insulin concentrations used in our study no change of the affinity was detected, however, such an additional alteration of insulin binding at lower insulin concentrations cannot be excluded. The "up-regulation" of the receptor may be explained by decreased insulin levels in the adrenalectomised rats. Decreased insulin levels after adrenalectomy have been described by several groups [41] and can be explained, at least in part, by reduced responsiveness of the B-cell of adrenalectomised rats to glucose [42]. The inverse relationship between insulin levels and receptor binding has been demonstrated in several experimental models not only in hyperinsulinaemia (for review see [43]), but also in states of insulin deficiency [13-19]. The changes in binding in the adrenalectomised group cannot be explained by their reduced food intake as is evident from the binding data of the sham-operated pair-fed group. This control group seemed to be important, as it is known that fasting induces an increase of insulin binding in rat adipocytes and human monocytes [14, 17, 44, 45].

Cortisol treatment of the adrenalectomised animals prevented the fall in serum insulin and possibly therefore the increase in insulin binding. Though high insulin levels could be achieved a change of the affinity of the receptor still can be observed. Thus cortisol deficiency alone leads to an increase of insulin binding suggesting a direct effect of cortisol on the insulin receptor. Cortisol treatment in vivo leads to a decrease in insulin binding $[39,46]$. Since in studies of Olefsky et al. cortisol in vitro had no direct influence on insulin binding in fat cells [47], this was explained as indirect effect mediated by increased insulin levels. The recent finding of Cigolini et al. [48], however, who could demonstrate a direct in vitro effect of cortisol on insulin binding in fat cells supports the above conclusion from our data. An influence of hormones other than insulin on the regulation of the insulin receptor was also demonstrated in experiments with hypophysectomised rats by Schoenle et al. [49].

The increased sensititivity of the fat cells of adrenalectomised rats towards insulin in submaximal doses without a change in the maximal effect can be explained by increased binding capacity of the cells, provided that the concept of "spare receptors" [50, 51] is applied. If the spare receptors are equally able to transmit the insulin signal, an increase of the receptor capacity should not influence the maximal insulin effect, but should lead to a shift of the doseresponse curve to the left [52] as is true in our model for glucose transport, lipogenesis and antilipolysis. It is questionable if the lower maximal over basal stimulation ratio of the glucose transport in the cells of the adrenalectomised group can be interpretated as a resistance, as the absolute transport values are higher in the cells of this group than in the cells of the sham-operated group.

Our results confirm earlier findings of Fernandez and Saggerson [25] on the antilipolytic effects of submaximal doses of insulin in adrenalectomised rats. On the other hand, insulin resistance has been 
described in these rats, if maximal insulin concentrations are administered and the antilipolytic [23] or lipogenic $[23,25]$ actions of the hormone are studied, which contrasts with our results. The upregulation of the binding capacity is not reflected in the sensitivity of the glucose oxidation, which indicates changes in the transmission of the insulin signal behind the receptor. The fact, that binding and action are not correlated in all situations was observed in other experimental models by a number of investigators $[14,16,17,49,53,54]$.

In addition to the well established phenomenon of an inverse relationship between insulin and receptor levels, our data suggest that cortisol might influence the insulin receptor as well. The hypersensitivity of the target tissue observed in our experiments might contribute to the clinical observation, that adrenal insufficiency in man is associated with the risk of hypoglycaemia and hypersensitivity to the administration of exogenous insulin.

Acknowledgement. We thank Eva Rattenhuber and Brigitte Fischer for the excellent technical assistance.

\section{References}

1. Kahn CR, Neville DM Jr, Gorden P, Freychet P, Roth J (1972) Insulin receptor defect in insulin resistance. Studies in the obese hyperglycemic mouse. Biochem Biophys Res Commun 48: 135-142

2. Freychet P, Laudat $M H$, Rosselin $G$, Kahn CR, Gorden $P$, Roth J (1972) Impairment of insulin binding to the fat cell plasma membrane in the obese hyperglycemic mouse. FEBS Lett 25: 339-342

3. Renner R, von Funcke HJ, Hepp KD (1976) The number of insulin receptors as a function of insulin levels in blood. Diabetologia 12: 416 (Abstr)

4. Le Marchand Y, Loten EG, Assimacopoulos-Jeannet F, Forgue M-E, Freychet P, Jeanrenaud B (1977) Effect of fasting and streptozotocin in the obese-hyperglycemic (ob/ob) mouse, apparent lack of direct relationship between insulin binding and insulin effects. Diabetes 20: 582-590

5. Soll AM, Kahn CR, Neville DM (1975) Insulin binding to liver plasma membranes in the obese hyperglycemic (ob/ob) mouse, demonstration of a decreased number of functionally normal receptors. J Biol Chem 250: 4702-4707

6. Olefsky JM (1976) Decreased insulin binding to adipocytes and circulating monocytes from obese subjects. J Clin Invest 57: $1165-1172$

7. Baxter D, Stanton K, Lazarus NR, Keen H (1978) The relation between insulin and adipocyte insulin receptors during treatment of human obesity. Eur J Clin Invest 8: 361-372

8. Archer JA, Gorden P, Gavin JR, Lesniak MA, Roth J (1973) Insulin receptors in human circulating lymphocytes: application to the study of insulin resistance in man. J Clin Endocrinol Metab 36: 627-633

9. Olefsky JM (1977) Insulin binding in diabetes: relationship with plasma insulin levels and insulin sensitivity. Diabetes 26: $680-688$
10. Gavin JR III, Roth J, Neville DM Jr, De Meyts P, Buell DN (1974) Insulin-dependent regulation of insulin receptor concentration: A direct demonstration in cell culture. Proc Natl Acad Sci USA 71: 84-88

11. Livingston JN, Purvis BJ, Lockwood DH (1978) Insulin induced changes in insulin binding and insulin sensitivity of adipocytes. Metabolism 27: 2009-2014

12. Blackard WG, Guzelion PS, Small ME (1978) Down regulation of insulin receptors in primary cultures of adult rat hepatocytes in monolayer. Endocrinology 103: 548-553

13. Hepp KD, Langley J, Funcke HJv, Renner R, Kemmler W (1975) Increased insulin binding capacity of liver membranes from diabetic Chinese hamsters. Nature 258: 154

14. Olefsky JM (1976) Effects of fasting on insulin binding, glucose transport and glucose oxidation in isolated rat adipocytes: relationship between insulin receptors and insulin action. $J$ Clin Invest 58: 1450-1460

15. Kasuga M, Akamuna Y, Iwamoto Y, Kosaka K (1977) Effects of fasting and refeeding on insulin receptors and glucose metabolism in rat adipocytes. Endocrinology 100: 1384-1390

16. Kasuga M, Akanuma Y, Iwamoto Y, Kosaka K (1978) Insulin binding and glucose metabolism in adipocytes of streptozotocin-diabetic rats. Am J Physiol 235: 175-182

17. Wieringa T, Krans HMJ (1978) Reduced glucose transport and increased binding of insulin in adipocytes from diabetic and fasted rats. Biochim Biophys Acta 538: 563-570

18. Davidson MB, Kaplan SA (1977) Increased insulin binding by hepatic plasma membranes from diabetic rats. Normalization by insulin therapy. J Clin Invest 59: 22-30

19. Schoenle E, Zapf J, Froesch ER (1977) Effects of insulin and NSILA on adipocytes of normal and diabetic rats: Receptor binding, glucose transport and glucose metabolism. Diabetologia 13: 243-249

20. Fraser R, Albright F, Smith PH (1941) The value of the glucose tolerance test and the insulin tolerance test in the diagnosis of endocrinological disorders of glucose metabolism. $\mathbf{J}$ Clin Endocrinol 1: 297-303

21. DeBodo RC, Steele R, Altszuler N, Dunn A, Bishop JS (1963) On the hormonal regulation of carbohydrate metabolism, studies with $\left[\mathrm{C}^{14}\right]$ glucose. Recent Prog Horm Res 19: 445-482

22. Manchester KL, Randle PJ, Jung FG (1959) The effect of growth hormone and of cortisol on the response of isolated rat diaphragm to the stimulation effect of insulin on glucose uptake and on incorporation of amino acids into protein. $\mathbf{J}$ Endocrinol 18: 395-408

23. Smith SJ, Saggerson ED (1977) Decreased sensitivity to insulin in white adipose tissue from adrenalectomized rats. Horm Metab Res 9: 474-480

24. Jeanrenaud B, Renold AE (1960) Studies on rat adipose tissue in vitro - VII. Effects of adrenal cortical hormones. J Biol Chem 235: 2217-2223

25. Fernandez BM, Saggerson ED (1978) Alterations in response of white adipocytes to insulin, noradrenaline, corticotropin and glucagon after adrenalectomy. Biochem J 174: 111-118

26. Rodbell M (1964) Metabolism of isolated fat cells. I. Effects of hormones on glucose metabolism and lipolysis. J Biol Chem 239: $375-380$

27. Vinten J, Gliemann J, Osterlind K (1976) Exchange of 3-0methylglucose in isolated fat cells. J Biol Chem 251: 794-800

28. Gliemann J, Osterlind K, Vinten K, Gammeltoft S (1972) A procedure for measurement of distribution spaces in isolated fat cells. Biochim Biophys Acta 286: 1-9

29. Eggstein M, Kuhlmann E (1974) Triglyceride und Glycerin. In: Bergmeyer HU (ed) Methoden der enzymatischen Analyse, 3rd ed. II. Verlag Chemie, Weinheim, p 1871-1878

30. Moody AJ, Stan MA, Stan M, Gliemann J (1974) A simple free fat cell assay for insulin. Horm Metab Res 6: 12-16 
31. Weitzel G, Renner R, Guiglielmi H (1971) Insulinähnliche Aktivität von Arginylverbindungen in vitro. Hoppe-Seylers $Z$ Physiol Chem 352: 1617-1630

32. Heding LG (1972) Determination of total serum insulin (IRI) in insulin treated diabetic patients. Diabetologia 8: 260-266

33. Zöllner N, Kirsch K (1962) Úber die quantitative Bestimmung von Lipoiden (Mikromethode) mittels der vielen natürlichen Lipoiden (allen bekannten Plasmalipoiden) gemeinsamen Sulphovanillin Reaktion. Z Ges Exp Med 135: 545-551

34. Lowry OH, Rosebrough NJ, Farr AL, Randall RJ (1951) Protein measurement with the folin phenol reagent. J Biol Chem 193: $265-275$

35. Di Girolomo A, Mendlinger S, Fertig JW (1971) A simple method to determine fat cell size and number in four mammalian species. Am J Physiol 221: 850-858

36. Leathem JH (1964) Some aspects of hormone and protein metabolic interrelationship. In: Munro HN, Allison JB (ed). Mammalian protein metabolism, vol I. Academic Press, New York, p 351-365

37. Fain JN (1962) Effects of dexamethasone and growth hormone on fatty acid mobilization and glucose metabolism in adrenalectomized rats. Endocrinology 71: 633-635

38. Olefsky JM, Johnson J, Lin F, Jen P, Reaven GM (1975) The effects of acute and chronic dexamethasone administration on insulin binding to isolated rat hepatocytes and adipocytes. Metabolism 24: 517-527

39. Goldfine ID, Kahn CR, Neville M, Roth J, Garrison MM, Bates RH (1973) Decreased binding of insulin to its receptors in rats with hormone induced insulin resistance. Biochem Biophys Res Commun 53: 852-857

40. Kahn CR, Goldfine ID, Neville MD, de Meyts P (1978) Alterations in insulin binding induced by changes in vivo in the levels of glucocorticoids and growth hormone. Endocrinology 103: $1054-1066$

41. Steele R (1975) Influences of corticosteroids on protein and carbohydrate metabolism. In: Handbook of physiology, Sect 7: Endocrinology, vol VI: Blaschko H, Sayer G, Smith AD (eds) Adrenal gland. Washington DC, Am Physiol Soc, p 135-167

42. Malaisse WJ, Malaisse-Lagae F, McGraw EF, Wright PH (1967) Insulin secretion in vitro by pancreatic tissue from normal, adrenalectomized and cortisol treated rats. Proc Soc Exp Biol Med 124: 924-928

43. Kahn CR, Roth J (1976) Insulin receptors in disease states. In: Levey GS (ed) Hormone-receptor interaction; molecular aspects. Marcel Dekker Inc, New York Basel, p 1-29

44. Olefsky JM, Kobaiyashi M (1978) Mechanism of the fasting induced increased insulin binding to rat adipocytes. $\mathbf{J}$ Clin Invest 61: 329-338

45. DeFronzo RA, Soman V, Sherwin RS, Hendler R, Felig P (1978) Insulin binding to monocytes and insulin action in human obesity, starvation, and refeeding. J Clin Invest 62: 204-213

46. Kahn CR, Goldfine ID, Neville DM Jr, Roth J, Bates RW, Garrison MM (1973) Insulin receptor defect: a major factor in the insulin resistance of glucocorticoid excess. Endocrinology 93: 168

47. Olefsky JM (1975) Effect of dexamethasone on insulin binding glucose transport and glucose oxidation of isolated rat adipocytes. J Clin Invest 56: 1499-1508

48. Cigolini M, Bosello O, Scuro LA, Smith U (1978) Interrelations between glucocorticoid hormones and insulin: The influence of cortisol on insulin binding to human fat cells in vitro. Diabetologia 14: 224 (Abstr)

49. Schoenle E, Zapf J, Froesch ER (1979) Receptor binding and effects of insulin and NSILA-S on glucose transport and metabolism in adipocytes from hypophysectomized rats. Diabetologia 16: 41-46

50. Kono T, Barham FW (1971) The relationship between the insulin binding capacity of fat cells and the cellular response to insulin. J Biol Chem 246: 6210-6216

51. Gliemann J, Gammeltoft S, Vinten J (1975) Time course of insulin-receptor binding and insulin-induced lipogenesis in isolated rat fat cells. J Biol Chem 250: 3368-3374

52. Kahn CR (1978) Insulin resistance, insulin insensitivity, and insulin unresponsiveness: A necessary distinction. Metabolism 27: $1893-1902$

53. Goldfine ID (1975) Binding of insulin to thymocytes from suckling and hypophysectomized rats. Evidence for two mechanisms regulating insulin sensitivity. Endocrinology 97: 948-954

54. Ip C, Teppermann HM, Holohan P, Teppermann J (1976) Insulin binding and insulin response of adipocytes from rats adapted to fat feeding. J Lipid Res 17: 588-599

Received: July 2, 1979,

and in revised form: March 25, 1980

Dr. H. Häring

Forschergruppe Diabetes

Kölner Platz 1

D-8000 München 40

Federal Republic of Germany 